\title{
Planning in Democratizing River Basins: The Case for a Co-Productive Model of Decision Making
}

\author{
Tira Foran ${ }^{1, *}$, David J. Penton ${ }^{1}$, Tarek Ketelsen ${ }^{2}$, Emily J. Barbour ${ }^{1}$, Nicola Grigg ${ }^{1}$, \\ Maheswor Shrestha ${ }^{3}{ }^{(0}$, Louis Lebel ${ }^{4}$, Hemant Ojha ${ }^{5}{ }^{\circledR}$, Auro Almeida ${ }^{6}$ and Neil Lazarow ${ }^{1}$ \\ 1 CSIRO Land and Water, GPO Box 1700, Canberra, ACT 2601, Australia; dave.penton@csiro.au (D.J.P.); \\ emily.barbour@csiro.au (E.J.B.); nicky.grigg@csiro.au (N.G.); neil.lazarow@csiro.au (N.L.) \\ 2 AMPERES, 38A Nguyen Thi Dieu, District 3, Ho Chi Minh City 700000, Viet Nam; tarek.ketelsen@gmail.com \\ 3 Water and Energy Commission Secretariat, Singha Durbar, Kathmandu 44600, Nepal; \\ maheswor2037@yahoo.com \\ 4 Unit for Social and Environmental Research, Faculty of Social Sciences, Chiang Mai University, \\ 239 Huaykaew Rd, Suthep, Mueang, Chiang Mai 50200, Thailand; louis@sea-user.org \\ 5 Institute for Studies and Development Worldwide (IFSD), 8/45 Henley Rd, Homebush West, NSW 2140, \\ Australia; hemant.ojha@ifsd.com.au \\ 6 CSIRO Land and Water, Private Bag 12, Hobart, TAS 7001, Australia; auro.almeida@csiro.au \\ * Correspondence: tira.foran@csiro.au
}

Received: 28 October 2019; Accepted: 21 November 2019; Published: 25 November 2019

\begin{abstract}
We reflect on methodologies to support integrated river basin planning for the Ayeyarwady Basin in Myanmar, and the Kamala Basin in Nepal, to which we contributed from 2017 to 2019. The principles of Integrated Water Resources Management have been promoted across states and regions with markedly different biophysical and political economic conditions. IWRM-based river basin planning is complex, resource intensive, and aspirational. It deserves scrutiny to improve process and outcome legitimacy. We focus on the value of co-production and deliberation in IWRM. Among our findings: (i) multi-stakeholder participation can be complicated by competition between actors for resources and legitimacy; (ii) despite such challenges, multi-stakeholder deliberative approaches can empower actors and can be an effective means for co-producing knowledge; (iii) tensions between (rational choice and co-productive) models of decision complicate participatory deliberative planning. Our experience suggests that a commitment to co-productive decision-making fosters socially legitimate IWRM outcomes.
\end{abstract}

Keywords: co-production; development assistance; hydrological modelling; irrigation; IWRM; rational choice; stakeholder participation; scenario analysis; water governance

\section{Introduction}

Strategic river basin planning consists of a complex, socially ambitious set of knowledge production practices, involving monitoring and assessment, expert-led analysis, and participatory planning [1,2]. This set of practices involves the production and synthesis of knowledge in multiple domains, the interpretation of key messages by policy actors, and the deployment of such messages in planning processes. Because they are complex, resource-intensive, and generally publicly funded, and because actors use them to justify particular investments or development trajectories, river basin planning practices deserve critical reflection.

In this perspective paper, we reflect on the processes and outcomes of two participatory river basin planning initiatives, to which — as process designers, implementers, and observers-we have contributed. One subset of the co-authors implemented an exploratory planning study for the 
Ayeyarwady river basin, completed in 2018 as a step towards a river basin master plan [3]. Another subset initiated Nepal's first participatory water resources development strategy for the Kamala, a $2050 \mathrm{~km}^{2}$ river basin in Nepal, an ongoing initiative as of 2019 [4]. These capability-constrained, post-conflict, democratizing settings offer vital insights into the strengths and limitations of approaches to strategic planning. The paper argues that IWRM-based planning requires co-productive models of planning. This argument is based on the authors' reflection on methodological challenges we navigated when designing and implementing river basin planning projects in Myanmar and Nepal.

The concept of strategic river basin planning has evolved since its emergence in the late 20th C. Until the 1990s, it essentially meant long-term infrastructural development planning, with relatively simple social or environmental analysis. Post-WWII water supply infrastructure was planned according to an engineering-oriented paradigm to meet certain objectives (such as irrigated agriculture and hydropower production) [1]. However, events preceding and during the 1990s revealed the social and environmental limitations of such paradigms to river basin development. Thailand and Nepal, for instance, debated the social acceptability of, and alternatives to, large hydropower dams $[5,6]$. After experiencing major floods in 1993 and 1995, the Netherlands came to recognise the limits of engineering practice, and the value of integrating spatial planning and water management $[7,8]$. In 1995, Australia announced a cap on diversions from the Murray Darling Basin, to avoid the ecological collapse of Australia's largest river system. At this time, a less fragmented, more coordinated, and systemic paradigm for water resources planning emerged, as reflected in the 1992 Dublin Statement on Water and Sustainable Development [9]. The Dublin Statement is the foundation for an integrated approach to planning water resources, subsequently promoted by development actors during the 2000s under the name of Integrated Water Resources Management (IWRM).

IWRM aspires to improve three "Es": efficiency, equity, and environmental sustainability [10]. It explicitly promotes the integration of multiple stakeholders, disciplines, and spatio-temporal scales [11]. However, within two decades of its emergence, practices to implement IWRM drew criticism for overly optimistic assumptions about how changes to water planning could deliver the three Es in unequal societies such as South Africa [10], Tanzania [12], and Nepal [13], and transboundary regions such as the Mekong basin. Contemporary IWRM is an ambiguous and diverse set of practices $[11,14]$. It includes top-down, principle-driven variants, as well as local-level, bottom-up, "expedient" versions $[15,16])$. The basin planning processes we reflect on in this paper have been influenced by highly aspirational IWRM principles, such as formulating a stakeholder-agreed development plan for the Ayeyarwady basin in Myanmar [17], or the desire among water agency professionals in Nepal to identify optimal development strategies using decision support systems. However, to realize — even partially — such aspirations, a river basin development plan would require meaningful participation and collaboration at, and across, multiple levels of governance [14].

Proponents of IWRM in developing countries face two notable political challenges. The first such challenge is asymmetry of knowledge and power, manifested as the uneven distribution of capability and authority between local and national government. Not only are water and land resources unevenly distributed in river basins, the capability of planners, as well as of affected people, is also concentrated at particular levels and locations (and decisions at one location or level can lead to unwanted consequences elsewhere in the system). For example, until recently, the unitary system of Nepal concentrated planning resources and capability at the centre. Power asymmetry can limit the recognition of local interests, knowledge, and socio-technical water management. It can prioritise national-level water resource development preferences. For example, large hydropower and inter-basin water diversion projects for irrigation have dominated planning conversations in Myanmar and Nepal, respectively $[18,19]$. The challenge of power asymmetry is exacerbated in contexts of data scarcity and uncertainty about river basins as social-ecological systems, where the state of the basin is influenced by political dynamics and narratives, as much as biophysical processes.

A second political challenge consists of the organizational mode by which IWRM initiatives have been delivered to developing countries. The recurring mode has been the international technical 
assistance project. Project modalities may constrain local interest and institutionalization, particularly when assistance is narrowly channelled. This risk is heightened in settings such as Myanmar and Nepal, which have restructured their water-related agencies and sought to establish new inter-agency water bodies. Although inter-agency coordination is challenging in any context, it is particularly acute in contexts of radical state restructuring, such as Nepal. Compounding these particular challenges, bureaucratic competition [20] and deficits of trust (between non-state and state actors, between lowerand high-level state actors) may arise.

The above conditions and dynamics have influenced the methods and techniques applied to river basin planning - the focus of this paper. Modern basin planning, which pre-dates IWRM, has favoured a particular set of expertise and stakeholders. For example, the expertise of hydrologists, engineers, lawyers, and national government officials tends to outweigh that of citizens, local officials, livelihood specialists, gender and social inclusion experts, and political economists [21]. The expertise and stakeholders favoured may insufficiently represent the breadth of water- and development-related concerns of people in large or complex river basins [22]. Even the production of disciplinary knowledge—such as a basin-scale surface water model—requires within-disciplinary diversity (e.g., rigorous peer-review) to be credible. The consumption of expert knowledge by non-experts requires accountability and transparency among knowledge producers (e.g., about the implications of uncertainty). When expertise, stakeholder concerns, interests, and relevant socio-technical options are inadequately included, legitimacy is compromised [18,23].

How can IWRM-based river basin planners increase the legitimacy of the strategic planning processes they design and facilitate? We engage with this question by reflecting on how particular methodological commitments, evident in our case studies from Myanmar and Nepal, exert influence on knowledge production and stakeholder participation. By "methodological commitments", we mean recurring preferences that we, as planning practitioners or stakeholders, exhibit towards particular methodologies (understood as conceptual models, and associated study designs and techniques). Such commitments can be explicit or tacit. The commitments discussed in this paper are inferences we have made, based on a review of key primary texts (e.g., terms of reference) and participant-observation.

To support such an interpretation, we use two models of how expertise and knowledge inform policy action. The first model is a rational choice model of decision-making [24,25]. In this model, an authorized decision maker (e.g., a minister, or ministerial council) makes decisions which allocate finite public resources so as to maximize societal utility, based on preferences voiced by citizens [26]. This model of expertise and choice assigns high responsibility to credentialed experts, who advise on the consequences of taking different socio-technical options. The second model is a co-productive model of decision-making. This model attaches relatively greater weight to the knowledge of non-credentialed experts. Through collaborative processes involving diverse actors, it seeks to produce agreement on shared goals, and to produce knowledge relevant to achieving those goals [27-30]. In the second model, authorities make decisions after recognizing, participating in, and responding to recommendations from co-productive processes (Section 3.2).

The two models of decision-making diverge on what constitutes actionable knowledge and how it should be produced (Section 3.2). Our case studies reveal the tensions that arise when both models co-exist in river basin planning. We describe our attempts to negotiate such tensions, and the consequences for planning of such negotiations. Our motivation is thus to reflect critically on the consequences of making particular methodological commitments, including those to which we contributed, for the purpose of improving IWRM-based planning.

Section 2 expands on the development contexts of Myanmar and Nepal. Section 3 then summarizes the original designs of the two river basin planning initiatives in Myanmar and Nepal, showing how their specific features originate in designs by water resource experts affiliated with international development partners. We also describe how specific commitments led to methodological tensions, which challenged us to revise or augment our original designs. Based on the insights from our two 
cases, Section 4 discusses implications for realizing IWRM-based river basin planning in developing countries. Section 5 concludes with recommendations.

\section{Water Resources Development Contexts: Myanmar and Nepal}

\subsection{Myanmar}

Since 2011, Myanmar's partial and contested democratization [18] has led to a notable increase in technical assistance by international development partners, to multiple sectors. In turn, since 2017, such assistance has yielded an efflorescence of water and water-related studies (e.g., [3,31-33]). Development technical assistance involves the promotion, by partners of national expertise (e.g., Australia and other donors in water resources modelling), of cooperation among partners to focus investment (e.g., an Australia-The Netherlands memorandum of cooperation around water resources assistance in Myanmar), as well as competition among partners promoting IWRM-based planning (e.g., Australia, The Netherlands) and those promoting infrastructural development (e.g., China, Japan, Korea).

In 2015, the World Bank initiated a Decision Support System and Basin Master Plan (herein, "Basin Master Plan") project for the Ayeyarwady river basin, as part of a \$100 M credit-financed initiative known as the Ayeyarwady Integrated River Basin Management Project. The 2018-2020 Basin Master Plan project is a major investment in evidence-based planning for Ayeyarwady. It aims to deliver a stakeholder-agreed basin development strategy for the Ayeyarwady, under the auspices of the National Water Resources Committee (NWRC), an inter-agency advisory body formed in 2015. Reaching agreement among a diversity of actors and interests is demanding in any context, let alone in the Ayeyarwady basin of Myanmar, where ethnic armed and quasi-state organizations contend for power and recognition against the Union government.

\subsection{Nepal}

Nepal's development context includes severe political instability that ended in the early 2000s, followed by a decade of negotiation that led to an agreement to create a federal state with a greater voice for citizens in historically marginalized regions of the country, and a state with more explicit commitments to gender equality and social inclusion. Since the enactment of the 2015 Constitution, Nepal has been undertaking a process of state restructuring, involving the devolution of authority and public revenue to seven new provincial-level governments, and 753 new local government bodies, with local and provincial elections held in 2017. The emergence of provincial agencies involved some transfer of authorities and personnel previously assigned to the central government. At the national level, state restructuring involved negotiations to reorganize and consolidate particular ministries, leading to the emergence of a Ministry of Energy, Water Resources, and Irrigation in 2017.

Since the early 1990s, hydropower development in Nepal has been based on principles of liberalization. Private investment, however, has been constrained by a number of financial and institutional risks [34]. In response, the national government has sought to support hydropower development through greater government involvement-identifying important projects, building national schemes and managing hydropower licensing issues [35]. Water and Energy Commission Secretariat (WECS) started a 2018-2021 study to prepare river basin plans and a hydropower development master plan of all river basins of Nepal, supported by strategic environmental and social assessment of these plans. As with the Ayeyarwady Basin Master Plan project, this is a major investment in strategic planning. It includes hydrological modelling, hydropower optimization studies, and strategic environmental and social assessment. The resultant river basin plans are intended to inform the selection of hydropower, irrigation and water supply infrastructure, as well as natural resource management projects in each basin. As with the Ayeyarwady Basin Master Plan project, this initiative will engage with multiple categories of stakeholder, including representatives of affected communities. In both cases, the process by which stakeholder consultations will lead to stakeholder-agreed outcomes is not explicitly stated $[17,36]$. 


\section{Methodological Commitments and Consequences}

\subsection{Formulating Strategy}

Our two river basin planning initiatives in Myanmar and Nepal had compatible aims and conceptual methodologies, focussed on the participatory formulation of strategy. Strategy refers to "the art or practice of planning the future direction or outcome of something especially of a long-term or ambitious nature" [37]. To strategize means to formulate courses of action to realize development values. Values are topics which matter (or arguably could matter) to an actor [38] (e.g., improving women's access to water, as proposed in Nepal's draft National Water Resources Policy [Section 3.4.1]). To strategize means to articulate goals, major means-to-goal, actions and responsible parties (Figure 1, "Development Pathways"). Strategizing further involves assessing the strengths and limitations of alternative courses of action to reach a goal (Figure 1, "Development Scenarios"). Such assessment can be done using techniques such as multi-criteria analysis (Kamala) and exploratory scenario analysis (Ayeyarwady). Development scenarios which have been prioritized through such assessment would then receive analysis to identify how they could be implemented (i.e., institutional and political economy analysis) [39-41] (Figure 1). In our case studies, strategies have the status of non-binding texts, which may mobilize further action and investment.

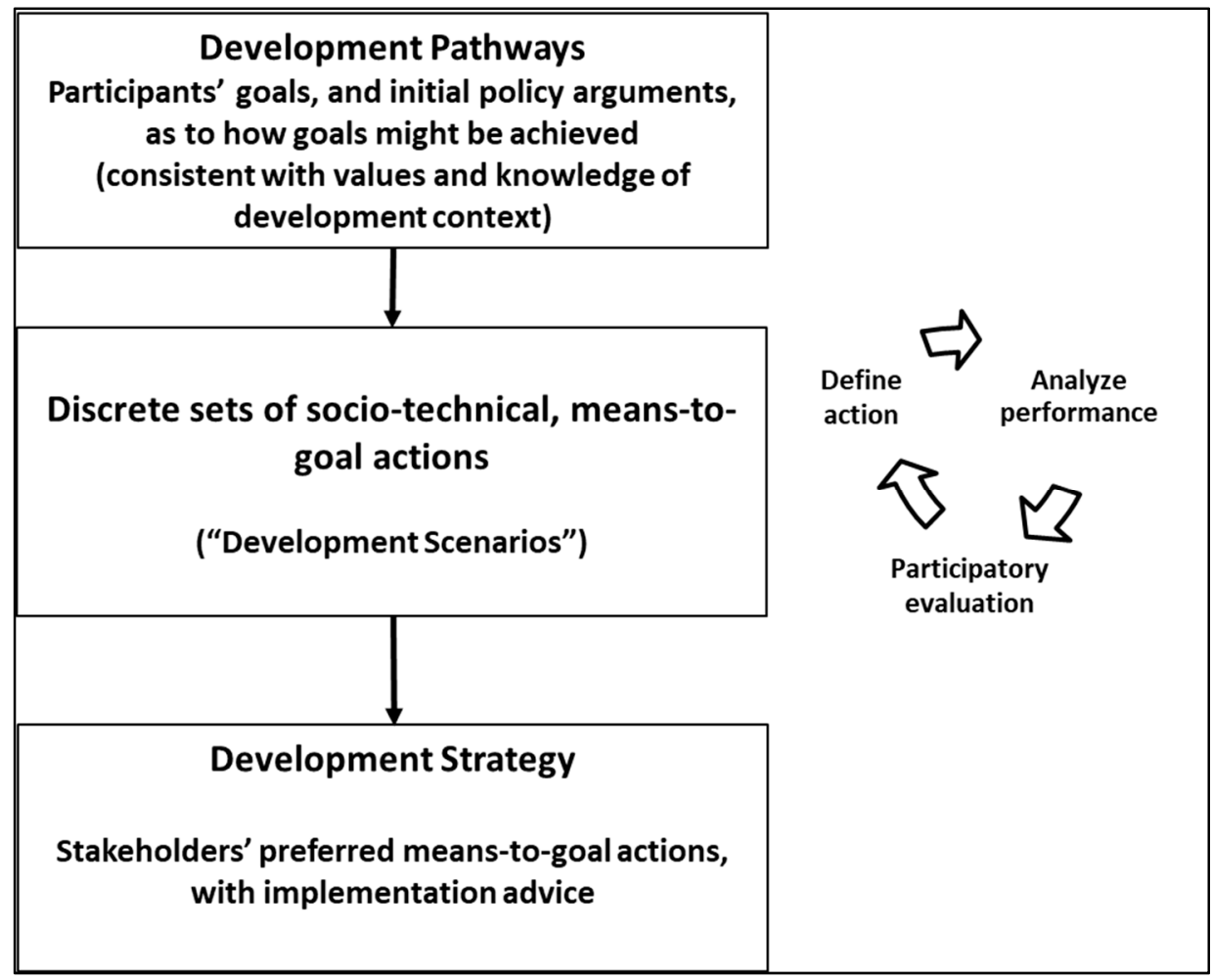

Figure 1. Participatory river basin planning: key components. Source: adapted from [3]. Note: definition of "development pathway" "development scenario", and "development strategy" based on our interpretation of [17]. Note: analysis of performance may use "exploratory scenarios" (Section 3.3).

To support participatory formulation of strategy, we anchored both projects to an explicitly deliberative and analytic methodology. By deliberation, we refer to dialogue and argumentation, which aim to generate advice on a set of alternative development strategies or options [38]. An emphasis on deliberation is justifiable, given the weaknesses of participation organized in a top-down, orchestrated manner [42]. Such weaknesses include a tendency to de-politicize values, goals, and means-to-goal actions, for example, by assessing means-to-goal actions using a limited range of evaluation criteria. Accordingly, we reviewed scientific and grey literature on planning approaches which were both 
technically-informed, and participatory [1,43-46]. In addition, we reviewed literature on specific relevant methods or techniques, such as scenario formulation [3] (chapter 3), multi-criteria analysis [47, 48], and hydrological modelling [3] (chapter 4, 8).

With respect to grey literature, we drew in particular on terms of reference for the Ayeyarwady Basin Master Plan project [17], on the basis that Nepal and Myanmar share broadly comparable development contexts, and common water sector development partners. (The Ayeyarwady Basin Master Plan project also includes the preparation of operational plans, and investment plans-however, these outputs were beyond the scope and resources of the Kamala initiative.)

\subsection{Collaborative Model of Governance, Co-Productive Model of Decision-Making}

An IWRM-based river basin planning process demands meaningful stakeholder participation. In order to facilitate such participation, we based both initiatives on a collaborative model of governance. Emerson et al. [49] describe collaborative governance as working via three processes, which may interact in a virtuous cycle over time. Each process requires particular kinds of interactions between individuals or small groups:

(i) Principled engagement. This refers to interactions that lead to participants understanding each other's interests. Principled engagement requires sufficient initial levels of trust and accountability. It may further emerge through reasoned argument and deliberation, focussed on defining problems and finding agreements together. In order to facilitate reasoned and reflective argumentation, we applied a framework which allows facilitators and participants to distinguish different components of a practical policy argument [3]. Over time, principled engagement enables "shared motivation".

(ii) Shared motivation. Shared motivation emerges from interactions that build trust, foster mutual recognition of interdependence, established shared ownership, and create a sense of internal legitimacy.

(iii) Capacity for joint action. Joint action refers to mobilisation of knowledge and resources, leading to outputs and outcomes that cannot be accomplished by any policy actor working in isolation, such as recommendations to reform institutional arrangements.

Our river basin planning initiatives sought to catalyse the first two phases of collaborative governance, mentioned above. We proposed designs which were iterative (repeated interactions among a core set of stakeholders); incremental (outputs from earlier activities directly influencing subsequent activities), and deliberative (e.g., use of participatory multi-criteria analysis to support structured argument about water augmentation options in Nepal) (see Figures 2 and 3 below). In doing so, we sought to realize the essence of a co-productive model of decision-making in planning, within the limitations of each project (such as language barriers, constrained access to local level stakeholders, and budgetary constraints). In this model, multiple state and non-state actors build knowledge together via processes they value (e.g., processes they regard as credible, legitimate, relevant), leading in turn to outcomes they value (e.g., a strategy regarded as legitimate; citizenship regarded as empowered) [27]. By contrast, in a rational choice model of decision-making, a much narrower group of (elite) policy actors processes information provided by stakeholders and experts, and maximizes societal welfare on the basis of such inputs [24].

Table 1 summarizes the essential components, and important variants, of rational choice and co-production models of decision-making. The models are ideal-types, on a spectrum of models of decision-making. (For example, instrumental versions of co-productive decision-making overlap with variants of rational choice which seek diverse expertise to improve problem and solution framing.) Nonetheless, the models differ with respect to how they conceptualize the process of taking authoritative decisions. 


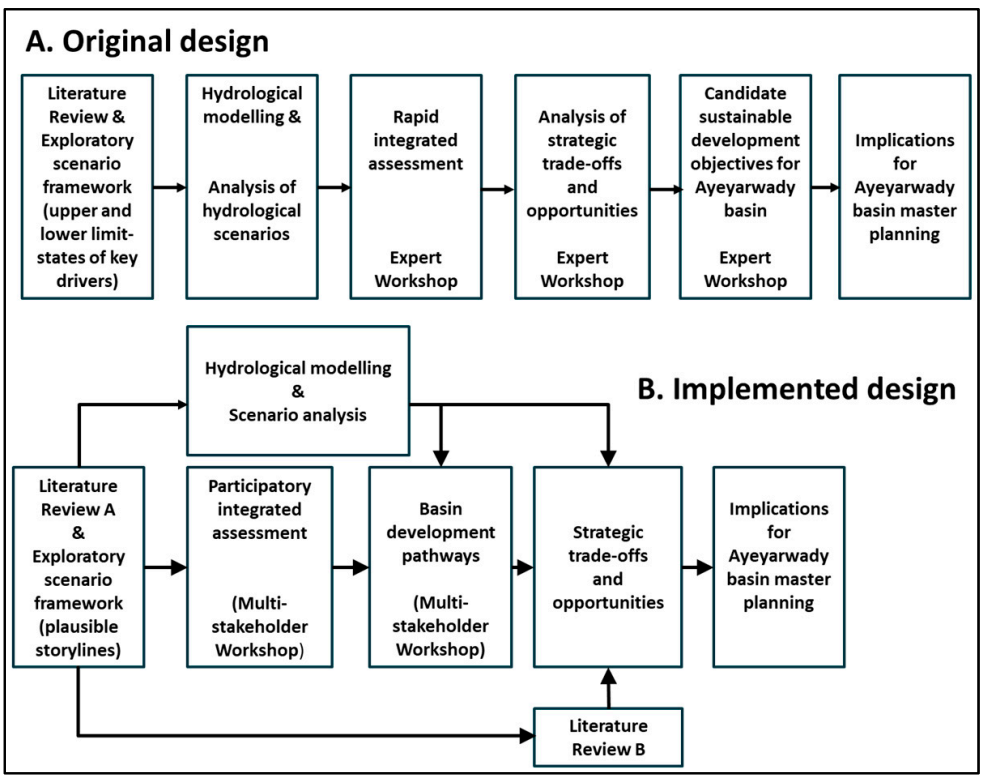

Figure 2. Ayeyarwady Basin Exploratory Scoping Study: original and implemented study designs.

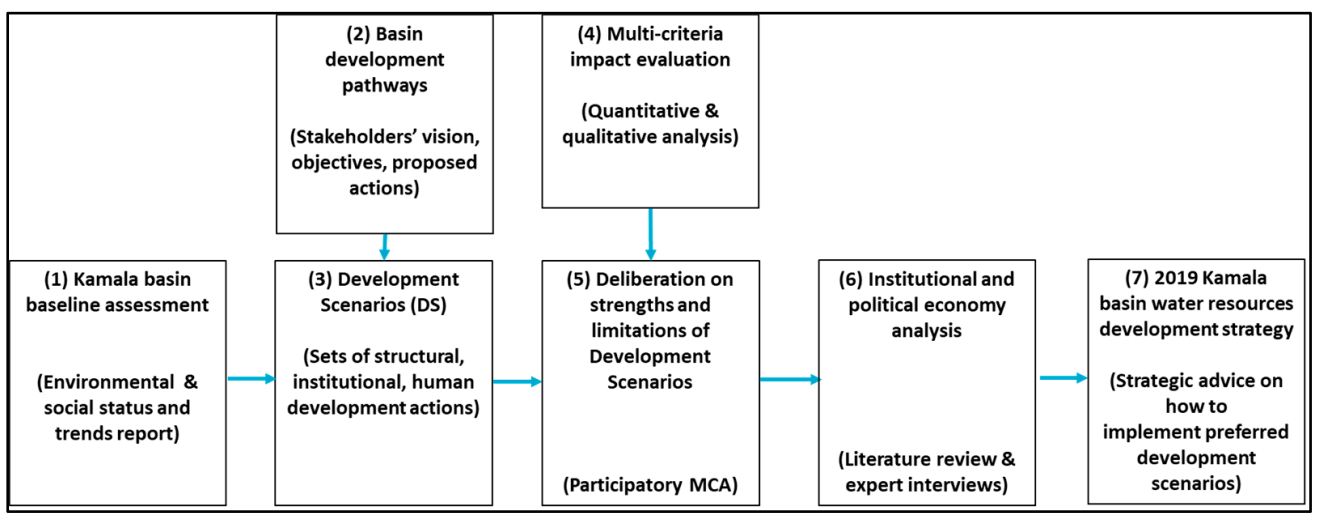

Figure 3. Kamala basin water resources development strategy: implemented study design. Note: Certain proposed actions were not feasible to evaluate using MCA, given resource constraints.

Table 1. Models of decision-making in planning.

\begin{tabular}{|c|c|c|}
\hline Components & Rational Choice Model & Co-Production Model \\
\hline Typical style of water governance & Hierarchical & Collaborative (network) \\
\hline Typical governance regime & Centralized & Polycentric \\
\hline Knowledge-policy linkages & $\begin{array}{l}\text { Relatively compartmentalized } \\
\text { interactions }\end{array}$ & Interactions bridging across roles \\
\hline $\begin{array}{l}\text { Assumptions about actors' core } \\
\text { roles and capabilities: (A) State } \\
\text { authorities (bureaucrats, } \\
\text { politicians) }\end{array}$ & $\begin{array}{c}\text { Interpret and process relevant } \\
\text { information provided by (B) and (C) } \\
\text { Maximize societal utility on basis of } \\
\text { inputs from (B) and (C) }\end{array}$ & $\begin{array}{l}\text { Co-design processes } \\
\text { Participate in analysis and deliberation } \\
\text { Legitimize collaborative processes } \\
\text { through recognition, and responding to } \\
\text { key outputs }\end{array}$ \\
\hline (B) Credentialed experts & $\begin{array}{l}\text { Generate substantive findings } \\
\text { Translate findings into } \\
\text { recommendations }\end{array}$ & $\begin{array}{c}\text { Co-design processes (may lead) } \\
\text { Facilitate (documenting outputs \& } \\
\text { outcomes of key activities) } \\
\text { Participate in analysis and deliberation }\end{array}$ \\
\hline $\begin{array}{l}\text { (C) Non-credentialed experts \& lay } \\
\text { people }\end{array}$ & $\begin{array}{l}\text { Communicate preferences to }(\mathrm{A}) \text { and } \\
\text { knowledge of impacts to }(\mathrm{B})\end{array}$ & $\begin{array}{l}\text { Co-design processes } \\
\text { Participate in analysis and deliberation } \\
\text { (may lead) }\end{array}$ \\
\hline Time requirements & Low to moderate ${ }^{1}$ & Moderate to high $^{2}$ \\
\hline Notable variants & $\begin{array}{l}\text { Recognition of, and actions to mitigate, } \\
\text { the effect of "non-rational" influences } \\
\text { on (A), such as emotions and heuristics }\end{array}$ & $\begin{array}{l}\text { Coproduction of public services } \\
\text { Participation as instrumental means }\end{array}$ \\
\hline
\end{tabular}

Source: Authors, based on [24,27]. Notes: ${ }^{1}$ Proportionate to cognitive complexity; assumes non-conflictual relations between actors. ${ }^{2}$ Proportionate to cognitive and political complexity [50]. 
Table 1 refers to governance regimes [51]. We understand the polycentricity of a governance regime as (i) the degree to which power is distributed among centers of authority (centralized vs. distributed), and (ii) the degree to which effective coordination between authorities exists (highly coordinated vs. fragmented) [52]. A rational choice model of decision-making in planning is typically associated with a centralized and coordinated governance regime, and a co-productive model typically associated with a polycentric (i.e., distributed and coordinated) regime, but such association is not a necessary property of either type of governance regime.

Among the project teams of both planning initiatives (Table 2), the rational choice model of decision-making co-existed with a co-productive model. The following two sections describe the tension between these methodological commitments, and the consequences for river basin planning.

Table 2. Summary: key elements of river basin planning initiatives (this paper).

\begin{tabular}{|c|c|c|}
\hline Element & $\begin{array}{c}\text { Initiative } 1 \text { (Ayeyarwady Basin, } \\
\text { Myanmar) }\end{array}$ & Initiative 2 (Kamala Basin, Nepal) \\
\hline Aim & $\begin{array}{l}\text { Enhance capability of state and } \\
\text { non-state actors to participate in } \\
\text { strategic river basin planning by } \\
\text { demonstration of relevant techniques }\end{array}$ & $\begin{array}{c}\text { Enhance capability of (primarily) state } \\
\text { actors to formulate a river basin } \\
\text { development strategy }\end{array}$ \\
\hline Objectives & $\begin{array}{c}\text { Explore uncertain long-term futures } \\
\text { Characterize hydro-physical processes } \\
\text { Facilitate dialogue around challenges, } \\
\text { goals, and possible development } \\
\text { pathways }\end{array}$ & $\begin{array}{l}\text { Define actions and investments to support } \\
\text { objectives such as: } \\
\text { - improving accessibility, quality and } \\
\text { reliability of water resources across the } \\
\text { basin; } \\
\text { - improving quality of life and } \\
\text { environmental standards; } \\
\text { - improving representation of women and } \\
\text { marginalised people }\end{array}$ \\
\hline Timeframe & $\begin{array}{l}\sim 12 \text { months (plan) } \\
\sim 20 \text { months (implemented) }\end{array}$ & 18 months (plan) \\
\hline Status (October 2019) & Completed & In progress \\
\hline Focal agency & Hydro-Informatics Centre (HIC) & $\begin{array}{l}\text { Water and Energy Commission Secretariat } \\
\text { (WECS) }\end{array}$ \\
\hline Key participants & $\begin{array}{l}\text { Seven national-level agencies } \\
\text { Two metropolitan agencies } \\
\text { Six non-state organizations } \\
18 \text { Young Water Professionals }\end{array}$ & $\begin{array}{c}\text { Seven federal agencies } \\
12 \text { local agencies } \\
\text { One provincial agency } \\
\text { Two non-state organizations } \\
\text { (as of June 2019) }\end{array}$ \\
\hline $\begin{array}{l}\text { Focal agency control over } \\
\text { implementation } \\
\text { Methodology: }\end{array}$ & Relatively low & Relatively high \\
\hline $\begin{array}{l}\text { Model of decision-making } \\
\text { in planning }\end{array}$ & $\begin{array}{l}\text { Rational choice (original design) } \\
\text { Collaborative (implemented design) }\end{array}$ & $\begin{array}{l}\text { Collaborative (original design) } \\
\text { Hybrid }^{2} \text { (implemented design) }\end{array}$ \\
\hline Development pathways & \multicolumn{2}{|c|}{$\begin{array}{l}\text { Core focus: Formulated by stakeholders } \\
\text { (two rounds of workshops) }\end{array}$} \\
\hline Exploratory scenarios & $\begin{array}{l}\text { Core focus: three narrative storylines } \\
\text { illustrated with hydrological model runs }\end{array}$ & Secondary focus (desktop analysis) \\
\hline Development scenarios & Not in scope & $\begin{array}{l}\text { Core focus (four scenarios illustrated with } \\
\text { hydrological model runs) }\end{array}$ \\
\hline Participatory assessment & $\begin{array}{l}\text { Rapid integrated assessment workshop } \\
\text { (March 2018) }\end{array}$ & Multi-criteria analysis workshop (May 2019) \\
\hline $\begin{array}{l}\text { Institutional \& political } \\
\text { economy analysis }\end{array}$ & Secondary focus (literature review) & $\begin{array}{l}\text { Core focus (literature review \& primary } \\
\text { data collection) }\end{array}$ \\
\hline
\end{tabular}

${ }^{2}$ Refers to co-existence of both models (Section 3.4).

\subsection{Initiative 1: An Exploratory Scoping Study for the Ayeyarwady Basin, Myanmar}

\subsubsection{Origins and Actors}

The Ayeyarwady Basin Exploratory Scoping Study (BESS) was designed to help bridge the gap between the Ayeyarwady State of the Basin (SOBA) assessment, and the World Bank-supported Basin Master Plan project. BESS was sponsored by the Australian Water Partnership, Myanmar Directorate 
of Water Resources and Improvement of River Systems (DWIR), and the Australian science agency CSIRO. The focal agency, HIC, is a project-based entity affiliated with the National Water Resources Committee (NWRC). NWRC is an inter-agency group formed in 2015 to advise on water-related risks and development. Implementing partners consisted of Chiang Mai University-Unit for Social and Environmental Research (CMU-USER), eWater Ltd., Flow Matters Pty Ltd., International Centre for Environmental Management (ICEM), and CSIRO.

With respect to participation in BESS, given the project's exploratory scope, advisors to the Basin Master Plan project recommended that a small subset of stakeholders, based primarily in Yangon and Nay Pyi Taw, be recruited. Participation in BESS primarily meant contributing to structured small group discussions in two one-day workshops: a rapid integrated assessment workshop (March 2018), and a development pathways workshop (May 2018). The agreed participant pool consisted of four categories of actors:

(A). Advisory Group (AG) to the National Water Resources Committee. The advisors comprise a small number of senior experts, some of whom are former government officers;

(B). Officers and young professionals affiliated with HIC's Young Water Professionals (YWP) and Junior Researcher programs, whom we invited and trained to serve as rapporteurs and task facilitators for project workshops;

(C). Officers of government agencies other than DWIR. We invited agencies responsible for domains of central relevance to strategic basin planning to nominate technical or policy experts to participate in the project workshops. Those domains included hydropower, forest conservation, irrigation development, pollution control, rural water provision, and urban planning;

(D). Representatives of civil society and research organizations. Criteria for recruitment included organizations with an interest in strategic water-related planning, or with a reputation for previous substantive work on a related topic, or having a prior contribution to the SOBA. We invited both domestic and international organizations, with a preference for Myanmar nationals.

For participation in the final, development pathways workshop, all attendees of the first workshop were invited. In addition, a small set of new organizations and individuals were invited, selected on the basis of their expertise on issues the team considered important (e.g., agricultural development).

\subsubsection{Methodological Commitments}

In addition to its capacity building objectives, sponsors conceived of BESS as an opportunity to provide an independent, expert perspective on risks, opportunities, trade-offs, and synergies in the Ayeyarwady basin [53]. BESS aimed to demonstrate the complex social-ecological implications of resource development decisions. In so doing, BESS could demonstrate the value of an inclusive, integrated human-environment approach, and offer guidance on the development of the subsequent Basin Master Plan project.

Specifically, designers wanted BESS to offer a consolidated understanding of the basin as a hydro-ecological system. This understanding would include the degree to which hydro-physical changes would lead to a change in ecological functioning. The hydro-physical changes of interest included change to land use/land cover (notably from forest conversion or restoration) and changes to flow regimes from the development of water storage for hydropower and irrigation. The effects of interest included impacts on sediment dynamics, fisheries, flooding, and navigation. This consolidated understanding was of interest to BESS' sponsors, because they anticipated that the Basin Master Plan project would emphasize the extent of unrealized natural resource development opportunities, in a manner similar to the Basin Development Plan program of the Mekong River Commission [54].

As shown in Figure 2 below, the original design of BESS focussed on hydrological scenario analysis as an entry point to an understanding of environmental and social impacts. The hydro-physical scenarios would inform a rapid integrated assessment, based on expert judgement. This assessment of ecological and social responses—-to be provided in a semi-qualitative manner by specific experts 
who had co-authored the SOBA-would then allow the team to draw conclusions about development opportunities and trade-offs for the Basin. In addition, the design called for the study team to formulate "candidate" development objectives, for example, water levels that should be maintained to allow year-round navigation between key cities. The envisioned timeframe for the study was approximately 12 months, with the intent of influencing the design phase of the DSS/Basin Master Plan project.

\subsubsection{Consequences for River Basin Planning}

The original design and methodology for BESS had an ambitious goal (the synthesis of key development opportunities and trade-offs); a broad scope yet short timeframe; and a particular emphasis on hydro-ecological impact assessment. In attempting to implement this design and methodology we experienced several constraints, tensions and contradictions, which are notable from the perspective of IWRM. These challenges required that we adapt and augment the original methodology, as described below.

The original design emphasized hydrological modelled scenarios and hydro-ecological knowledge. The Ayeyarwady hydrological model allowed us to explore the impacts on surface water resources availability under three exploratory scenarios (described below), and to describe notable alterations to flow regimes at the sub-basin level [3].

To conduct the above analysis, it was necessary to translate qualitative narratives to quantitative modelled scenarios. We made modelled outputs available to participants via an online dashboard, presentations from modellers and access to modellers for questions during workshops. However, we experienced several challenges. Some aspects of particular interest to stakeholders (e.g., navigability) were not explicitly modelled. Model parameterisation also required assumptions that could only be partially tested, given the scarcity of observational data [3] (chapter 4). For example, configuring storages in the model required assumptions about operational rules, yet these details are not always known for existing storages, let alone planned facilities. The impacts of hydropower development on downstream flows were sensitive to such assumptions. We made assumptions that stakeholders and modellers regarded as appropriate, choosing operating rules that maximise the impact of hydropower options on the seasonal hydrograph. Such challenges contributed to our decision to complement the modelling with more intensive stakeholder involvement in the impact assessment process.

Time delays incurred during the activities above meant that we were not able to enlist a sufficient number of the original SOBA co-authors, to conduct the rapid integrated assessment (essentially, an estimate of alternative bundles of ecosystem goods and services that the Ayeyarwady basin could provide under the exploratory hydrological scenarios). This delay had implications for the production of the rapid integrated assessment (Figure 2, " $\mathrm{A}$ ") and for overall project delivery. In order to deliver, within an acceptable timeframe, an assessment of strategic trade-offs and opportunities-a key intermediate output-it was necessary to make several interlinked revisions to the design. These revisions amounted to a move from a multi-disciplinary to a transdisciplinary practice [30].

First, to conduct a rapid ecological and socio-economic impact assessment, assumptions about future states were required to complement the hydrological modelled scenarios. We therefore developed three "Ayeyarwady 2055" exploratory scenarios. These storylines depicted imagined future conditions in upland and lowland zones of the Ayeyarwady basin, based on an initial set of drivers and outcomes that were explicitly social and political, as well as bio-physical. The storylines conveyed essential social and economic dynamics. Although the hydrological scenarios remained analytically distinct, we conceptualised them as devices to illustrate the storylines [3] (pp. 9-44). In so doing, we made them more accessible to a non-specialist set of participants.

Second, the original design focused heavily on hydrological scenarios and made the expertise of the SOBA authors prerequisites for stakeholder discussion about strategic issues. This was consistent with a rational choice model where authority is vested with experts; however, we revised the technique to be more conducive to co-production of knowledge. Our first workshop invited a set of state and non-state stakeholders in Myanmar to discuss such issues using their existing knowledge (Figure 2). 
In so doing, we mobilized a wider set of expertise, beyond that of disciplinary specialists (cf., [45]). To motivate this discussion about impacts, risks and opportunities, participants first read and discussed the Ayeyarwady 2055 scenario storylines. The integrated assessment workshop elicited a wide range of development issues which the participants regarded as significant. Participants provided insights regarding the broader, cross-sectoral impacts ssociated with upland and lowland resource development [3] (pp. 45-51).

Our subsequent "development pathways" workshop (Figure 2, "B") invited a broader cohort of participants than was conceived in the original design to formulate major sequences of public actions to attain development objectives, to which, as citizens of Myanmar, they might reasonably aspire [3]. Participants formulated objectives to improve water quality, upland forest and catchment governance, sediment management, electrification, and agricultural development. They articulated ambitious goals and proposed reasonable and relevant sets of objectives linked to each goal. For each objective, they generated actions, ranging from concrete, incremental steps, achievable in the short term, to more complex actions. Some of the latter are ambiguous, and will require clarification and elaboration. Many of the pathways require transformative changes (for example, peace agreements with inclusive approaches to upland catchment management) [3] (pp. 52-60). The study then explored the gap between such aspirations, and dynamics-as-usual trajectories of development in the Ayeyarwady basin. It concluded by reflecting on the implications of its methodology for the ongoing Basin Master Plan project.

\subsection{Initiative 2: Water Resources Development Strategy for Kamala Basin, Nepal}

\subsubsection{Origins and Actors}

Government of Nepal's Water and Energy Commission Secretariat (WECS) formulated a National Water Resources Strategy in 2002, and a National Water Plan in 2005. WECS provides other government agencies with a technical review of their development plans. Since the early 2000s, it has been the proponent of IWRM in Nepal, with IWRM officially recognised in the Water Resources Strategy [55].

In 2017, WECS intiated the formulation of a National Water Resources Policy. The draft policy proposes differentiated responsibilities for water management, consistent with the 2015 Constitution. Among other things, it proposes that a revitalized Water and Energy Commission and its Secretariat approve the periodic submission of strategic river basin plans. Further, it proposes that all three tiers of government, including the private sector, need to take techno-economic clearance (consent) from WECS to implement any new water resources development project in a river basin. WECS consequently identified that it would need to build hydrological and associated modelling capabilities, in order to support a techno-economic review of proposed water resource development plans and projects. For improving the capacity for multi-objective optimization for planning, as well as participatory planning, the Kamala river basin (population 610,000) was selected as an appropriate case. The implementing partners are WECS and CSIRO.

The participant pool for Kamala basin strategy formulation initially consisted of the following categories of actors, with A-F identified through a stakeholder analysis:

(A). Representatives of each of the Basin's 15 local government bodies (elected officials and/or senior staff);

(B). Representatives of approximately six national government agencies serving on the Advisory Committee to the project;

(C). Academic and consultant water and agricultural professionals;

(D). Officers of the Kamala Irrigation Project, Department of Water Resources and Irrigation;

(E). Civil society organizations representing ultimate beneficiaries;

(F). Representatives of private enterprises operating in the basin, and;

(G). Individual women and men, representing particular communities of ultimate beneficiaries. 
As of 2019, actual participants have come from categories A-D. These participants contributed to structured small group discussions in one or more of the following workshops: six visioning and goal setting workshops (July and November 2018), and a multi-criteria analysis workshop (May 2019). By contrast, participation of actors from categories $\mathrm{E}-\mathrm{G}$ has occurred through interviews and focus group discussions on selected topics (e.g., livelihoods and water use), as opposed to direct participation in strategy formulation.

\subsubsection{Methodological Commitments}

Figure 3 shows key steps in the methodology as of 2019. Those include participatory formulation of development pathways (following techniques used in Initiative 1); multi-disciplinary analysis impact assessment of development scenarios; participatory multi-criteria analysis (MCA) of development scenarios; and institutional and political economy analysis of preferred development scenarios, for the purpose of providing implementation advice. (The original study design [4] included additional techniques which the study team elected not to pursue because of resource constraints.)

The implemented design is consistent with a deliberative, analytic approach to strategy formulation. However, its detail and complexity has not been well suited to an operating context constrained by time, geographic distance, and disciplinary backgrounds. Furthermore, the scope of topics of interest to participants has been broad, in comparison with the project's resources and timeframe.

\subsubsection{Consequences for River Basin Planning}

Project constraints drew to light methodological tensions within the project team, as well as between stakeholders, where time, budget, resources and significant uncertainty dominated. As we explore in this section, tensions over prioritization included the acquisition of new data; the production of knowledge by technical experts; and the integration of stakeholder knowledge and participation in the planning process.

The complexities of design and technique led to disagreement across the project team about the significance of each technical component, its definition and necessity, and, hence, its relative priority in a context of constrained resources. For example, one position observed among the team was the prioritization of detailed baseline assessment, as well as the projection of future water demand and supply (Figure 3, step 1), as an important pre-requisite to strategy formulation. This position questioned the value of developing a strategic plan based on limited observational data. A contrasting position observed among the team was a belief that the central methodological challenge was, notwithstanding the inevitability of limited data, could any strategic advice be offered regarding two or more options to achieve key objectives (e.g., meeting agricultural water demand)?

One element in our response to this planning challenge was to use participatory multi-criteria analysis (MCA), a technique that could be iterated to incorporate new knowledge (Figure 3, step 5). Participants in the Kamala initiative had previously formulated three goals as part of their Development Pathways (Figure 3, step 2). The Pathways were formulated through the exchange between local and national government actors of values, goals, and means-goal actions. One of the three goals was a broad, water-centred development goal: "reduced impact of water induced disasters, and improved availability, use, and allocation of water resources for livelihood generation, well-being and economic growth" [56]. Participants envisaged several major actions that could meet this goal: building small or medium reservoirs; the conjunctive use of groundwater and surface water; and building a large inter-basin water transfer scheme (the Sun Koshi-Kamala multi-purpose diversion project [57]). The project team elaborated these actions, plus the rehabilitation of the existing Kamala Irrigation Project [58], into four Development Scenarios. Notwithstanding uncertainty about the status and trends of water supply and demand, the project partners eventually agreed to proceed with a participatory MCA workshop focussed on the Development Scenarios.

MCA is sensitive to prior understandings of a policy issue, and how particular options are described. The question of who evaluates has consequences for representation and legitimacy $[48,59]$-as such, 
we recommended inclusive participation. Our MCA design, adapted from [47], involved an impact evaluation conducted by the project team (based on desktop analysis, hydrological modelling, and expert interviews), for nine initial evaluation criteria. Participants individually weighed each criterion twice, before and after viewing evaluation results. The team computed individual utility scores. The median and distribution of individual scores for each Development Scenario were then viewed, as a contribution to the deliberation over prioritizing the Development Scenarios.

The focal agency regarded particular NGOs and research organizations as inappropriately politicized, or insufficiently prepared to engage in such deliberation. Consequently, we invited participants from the three levels of government, and a restricted set of research organizations. Such outcomes reflect unfamiliarity with public participation in the direct formulation of strategy (Figure 3). They further reflect relatively low trust, and perhaps relatively low mutual accountability, between state and non-state actors in Nepal's water sector (cf. Section 3.2). Such dispositions were concentrated among Nepali experts advising the focal agency, but at times were expressed by elected representatives. (In late 2018, some elected local government representatives told us that time constraints prohibited their direct participation in co-production of the water resources development strategy. Instead, they requested to review the team's analyses and recommendations, consistent with a rational choice model of decision-making. The local representatives did not express preferences regarding the participation of other actors)1. We reflect on the appropriateness of the methodological design in the following section.

\section{Discussion}

\subsection{Negotiating Mixed Methodological Commitments}

Figure 4 summarizes the consequences for river basin planning of the methodological commitments made in our Nepal and Myanmar initiatives. It summarizes the key influences on those commitments, as well as some responses to mitigate certain undesired consequences.

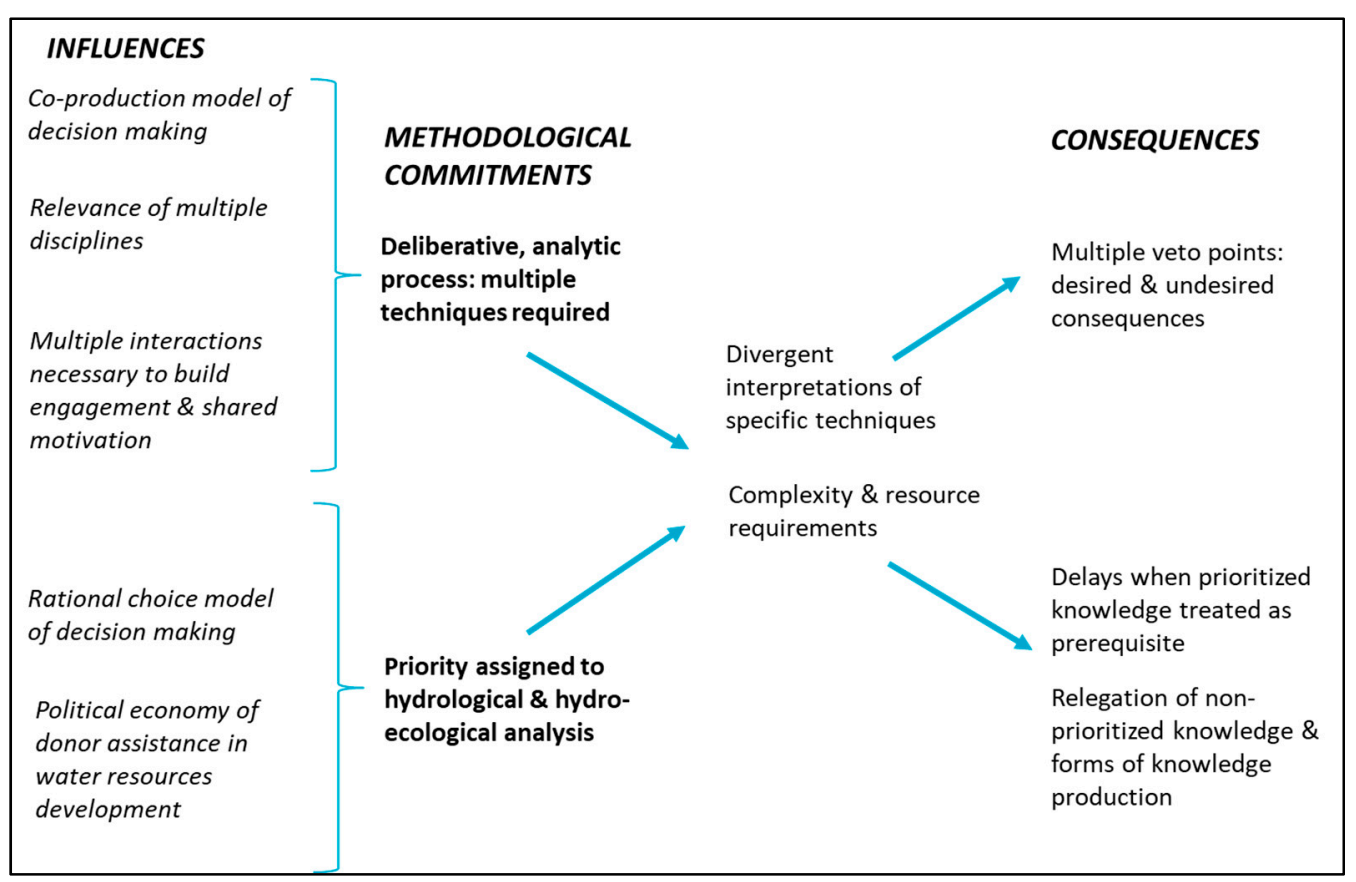

Figure 4. Methodological challenges for river basin planning in developing countries.

In both cases, more than one model of decision-making influenced original design commitments. In both cases, following a co-production model, one subset of the partners committed to using multiple disciplinary techniques to support an analytic deliberative process. On the other hand, consistent with a rational choice model, a second subset of the partners regarded specific expertise to be a prerequisite 
for participatory basin planning to commence. In both cases, the ensuing epistemological tension led the partners to occasionally disagree over technique prioritization and resource deployment. Both cases highlight the importance of fostering competencies and capacities to negotiate acceptable outcomes when such tensions arise.

In the Ayeyarwady case, challenges in producing and interpreting hydrological modelled scenarios offered the team an opportunity to adapt the rapid integrated assessment method (Figure 2). We widened it from a realtively narrow Delphi process to a process more inclusive of our workshop participants' social, political, and environmental knowledge. This adaptation met the project's overall objectives, but in a manner consistent with a co-productive model, not a rational choice model, of decision-making. By contrast, in the Kamala case, divergence over who could effectively contribute to MCA (Section 3.4.3) impacted discussion around the pros and cons of the four Development Scenarios.

When mixed methodological commitments lead to undesired consequences from an IWRM perspective, the specific autonomy of process designers matters. In the Myanmar case, our autonomy as process designers was relatively high, whereas in the Nepal case, it was relatively low (as manifested in constraints on the type of stakeholder, and types of knowledge production, admitted or preferred by the focal agency; Section 3.4.3). We interpret this difference in control primarily to contextual differences between Myanmar and Nepal. The Ayeyarwady BESS initiative-an exploratory study with lower stakes for the focal agency-allowed innovation with co-productive methods, with minimal contestation from advisors to the focal agency.

By contrast, the Kamala initiative aimed to produce an actual strategy, and to do so in a context of relatively profound state restructuring compared to Myanmar. Nepal's federal structure has constituted and mobilized local and provincial government actors. Concurrently, key organizations of federal government are in the process of restructuring, along with legislation reform. WECS is proposed to have significant institutional reforms in order to implement IWRM-based river basin planning. It takes time to adopt a co-production model of decision-making and a vigorous multi-stakeholder process. A deliberative analytic design (Figure 3) offers multiple points for project sponsors to intervene, occasionally exercising veto power, to shape the scope and extent of stakeholder participation (Figure 4).

To navigate undesired consequences when multiple techniques are required (Figure 4), we found it helpful to simplify essential techniques (Figure 3), and to propose planning processes that do not allow any one actor to dominate methodological choices (Ayeyarwady). In the Ayeyarwady case, the explicitly co-productive approach mitigated the risk of over-weighting biophysical analysis. In both cases, we found it helpful to affirm and elicit expertise from different disciplines. The ability to iterate contested or unimplemented techniques would further contribute to a shared understandinging of their value.

\subsection{Implications for Realizing Aspirations of IWRM}

We noted at the outset that IWRM-based river basin planning is a project with high aspirations, such as formulating a stakeholder-agreed development plan for the Ayeyarwady basin in Myanmar [17], or producing a river basin development strategy for the Kamala to realize an optimal set of economic, social, and environmental benefits [60].

Our attempts to further such aspirations led us to adopt analytic, deliberative methodologies, consistent with collaborative and co-productive models of decision-making. However, these are not without constraints. For example, authority and influence in water policy are concentrated among actors who are familiar with stakeholder consultation in the form of roundtable or town hall style meetings, but less familiar with the notion of empowering stakeholders to formulate strategy-based on analytic, deliberative methods. Furthermore, the institutions of river basin planning are nascent in developing, post-conflict settings.

A more subtle constraint arises from the fact that IWRM-based planning is logically consistent with a co-productive model of decision-making (and a collaborative style of governance)-yet, at a global level, development partners promoting IWRM-based planning predominately subscribe to a 
rational choice model of decision-making (and a hierarchical style of governance). They recognize the instrumental value of stakeholder consultation, but ultimately assign to specialists the task of formulating the options presented to decision takers (see e.g., design documents for the Myanmar BESS project [53] and the DSS/Basin Master Plan project [17]).

This presents a tension for development donors. On the one hand, a state-centric and hierarchical interpretation of IWRM is expedient, and may appear to be the only overarching model of technical assistance acceptable to recipient states. One the other hand, we have shown that contrasting understandings of how expertise links to action, and of what expertise should be prioritized, have important socio-political effects, some of which can undermine the inclusive aspirations of IWRM.

\section{Conclusions: Advancing Collaborative, Co-Productive IWRM}

This paper focussed on IWRM-based planning in Myanmar and Nepal, during a period in which we had the privilege of co-designing and implementing river basin planning initiatives (2016-2019).

During this period, the politics and institutions related to water resources development were dynamic and contested in both countries. We did not attempt a comprehensive diagnosis of the institutional and political constraints to realizing IWRM aspirations. Instead, by focusing on planning methodology in action, we offer insights to improve river basin planning practice in democratizing settings.

Both our planning initiatives made use of participatory, deliberative, analytical designs. Although such designs are consistent with a co-productive model of decision-making, they are complex. In a context of hierarchical governance, such designs offer many intervention or veto points. From the standpoint of realizing the aspirations of IWRM in democratizing settings, such points of interception have desirable and undesirable implications (Section 4.1). Nonetheless, when they apply co-productive knowledge production in and beyond the project cycle, donors and designers advance IWRM-based river basin planning.

Sponsors uncertain of participatory deliberative processes might draw confidence from the relative success of the multi-stakeholder visioning ("development pathways") components in our planning initiatives. In both cases, participants articulated broad development agendas for their river basins $[3,56]$. They expressed concern for marginalized people (e.g., landless farmers; people in conflict zones), and recommended equitable and ecologically sensitive investment in upland natural resources and farming. They proposed multiple water resources development options (and, in the Kamala, Nepal case, subsequently deliberated on them in detail). They believed their understanding of strategic issues improved, and that co-participants gave reasoned arguments for positions. Participants considered it important to contribute to river basin planning beyond their specific expertise-that is, beyond their instrumental value. They explicitly valued a collaborative multi-stakeholder approach to planning. Participants' evaluations from the Kamala development pathways and MCA workshops are consistent with evaluations obtained by the BESS project [3] (Annex 3).

Donors and designers can scrutinize IWRM technical assistance for the presence of rational choice models of decision-making, in order to reflect on advantages and limitations of their specific models. Sophisticated rational choice models recognize the potential for non-rational influences on decision-maker cognition. They recognize that it is not enough to present credible analysis to public actors who are assumed capable of acting on such knowledge to further their interests, in accordance with their values. However, even sophisticated rational choice models may underestimate the effect of power imbalances between actors, and externalize the challenges of political accountability (e.g., by assuming that elections or other accountability processes will ultimately steer authorities to maximize societal utility).

In the wider Mekong region, much authority to take decisions remains with agencies with the expertise to control floods, irrigate arid land, and otherwise meet water demand through infrastructural means [21]. However, consistent with IWRM principles, water resources development has grown considerably more complex in recent decades. It is evolving from technical optimization to integrated, 
systemic, foresight-oriented concerns [1]. Yet, state water agencies in the Mekong continue to privilege the original set of engineering and hydraulic expertise.

A co-productive model of knowledge production widens the scope of relevant expertise. The collaborative mode of governance underpinning it explicitly seeks to empower and mobilize civil society and private sector actors. We found that actors thus empowered can set the planning agenda. In the Ayeyarwady case, we found that co-production allows stakeholders to mitigate certain challenges encountered in scenario modelling (Section 3.3.3), and helps shape a planning process that can start immediately, even as data collection and model development continue in parallel. By working with planning stakeholders, we discovered more effective ways to combine and sequence disciplinary knowledge (Figure 2).

Our experiences in Myanmar and Nepal show that, with adequate support, stakeholders can co-design more vigorously, for example providing guidance for which disciplines are necessary and sufficient to address their agenda. We have shown the difficulties of trying to implement co-productive and collaborative models. Yet the alternative-managing complexity and contestation via bureaucratic modes of governance-offers no greater likelihood of planning outcomes legitimized by society (cf., [18]). Development partners instead can point to longstanding practices of collaborative planning in their own contexts. Australia, for example, can offer diverse models of collaborative governance, as reflected in the work of Landcare, Catchment Management Authorities, regional natural resource management bodies, and participatory urban planning initiatives. Such domains have yielded productive multi-stakeholder deliberative initiatives [47,61,62]; comparative insights on collaborative management $[63,64]$; insights on the challenges of integrating Indigenous knowledge into river basin planning [65]; and reflections on the interaction between collaborative and hierarchical governance [66,67].

In conclusion, methodologies are not neutral in their effects-they empower some actors at the expense of others. IWRM initiatives in democratizing developing countries face multiple challenges. While the rational choice model of decision-making which persists in IWRM-based planning offers an administratively simpler approach to development assistance, it runs the risk of unduly concentrating expertise and power. In so doing, it undermines the ultimate aspirations of IWRM, which require co-productive approaches. We hope the insights offered as a result of our experience can guide improved IWRM investments and outcomes.

Author Contributions: Conceptualization, T.F.; methodology, T.F.; writing-original draft preparation, T.F.; writing—review and editing, T.F., D.J.P., M.S. (Nepal), T.K., E.J.B., N.G., L.L., H.O., A.A., N.L.; project administration, T.F., M.S. (Nepal), D.J.P., A.A., N.L.

Funding: This perspective piece contributes to the South Asia Sustainable Development Investment Portfolio supported by the Australian Aid progam. It was co-funded by CSIRO Land and Water.

Acknowledgments: We thank three anonymous reviewers, Saumitra Neupane, William Young, S.M. Wahid, and Susan Cuddy, for comments provided during the writing process. We acknowledge the Advisory committee for Kamala Basin Initiative, the Australian Water Partnership, eWAter Ltd., Jalsrot Vikas Sanstha, and Policy Entrepreneurs Inc.

Conflicts of Interest: The authors declare no conflict of interest. The funders had no role in the design of this communication piece; in the collection, analyses, or interpretation of data; in the writing of the manuscript, or in the decision to publish the results. Research carried out in the Kamala basin is a collaborative work between WECS and CSIRO.

\section{References}

1. Guy, P.; Li, Y.; Tom Le, Q.; Robert, S.; Li, J.; Shen, F. River Basin Planning: Principles, Procedures and Approaches for Strategic Basin Planning; UNESCO: Paris, Frence, 2013.

2. Cook, C.; Bakker, K. Water security: Debating an emerging paradigm. Glob. Environ. Chang. 2012, 22, 94-102. [CrossRef]

3. Foran, T.; Grigg, N.; Barbour, E.; Wahid, S.; Gamboa Rocha, A.; Hunter, R.; Sawdon, J.; Moolman, J.; Adams, G.; Rahman, J.; et al. At the Heart of Myanmar: Exploring Futures of the Ayeyarwady River System. Ayeyarwady 
Basin Exploratory Scoping Study (BESS). Final Report; eWater Ltd. (Australian Water Partnership): Canberra, Australia, 2019; Available online: https://www.airbm.org/wp-content/uploads/2019/03/Ayeyarwady-BasinExploratory-Scoping-Study-BESS-Final-Report.pdf (accessed on 25 November 2019).

4. Foran, T.; Almeida, A.; Penton, D.; Shrestha, M. Participatory river basin planning for water resource management in Kamala Basin, Nepal. In Proceedings of the International Commission on Irrigation and Drainage (ICID), 8th Asian Regional Conference, Kathmandu, Nepal, 2-4 May 2018; Available online: http://www.icid.org/8arc_postproceedings.pdf (accessed on 24 November 2019).

5. Foran, T.; Manorom, K. Pak Mun Dam: Perpetually Contested. In Contested Waterscapes in the Mekong Region: Hydropower, Livelihoods and Governance; Molle, F., Foran, T., Käkönen, M., Eds.; Earthscan: London, UK, 2009; pp. 55-80.

6. Dixit, A.; Gyawali, D. Nepal's constructive dialogue on dams and development. Water Altern. 2010, 3, 106.

7. Wolsink, M. River basin approach and integrated water management: Governance pitfalls for the Dutch Space-Water-Adjustment Management Principle. Geoforum 2006, 37, 473-487. [CrossRef]

8. Bergsma, E. Expert-influence in adapting flood governance: An institutional analysis of the spatial turns in the United States and the Netherlands. J. Inst. Econ. 2017, 14, 449-471. [CrossRef]

9. The Dublin Statement on Water and Sustainable Development. In Proceedings of the International Conference on Water and Environment (ICWE), Dublin, Ireland, 26-31 January 1992.

10. Molle, F. Nirvana concepts, storylines and policy models: Insights from the water sector. Water Altern. 2008, 1, 131-156.

11. Medema, W.; McIntosh, B.S.; Jeffrey, P.J. From Premise to Practice: A Critical Assessment of Integrated Water Resources Management and Adaptive Management Approaches in the Water Sector. Ecol. Soc. 2009, 13, 29. [CrossRef]

12. van Koppen, B. Winners and Losers of IWRM in Tanzania. Water Altern. 2016, 9, 588-607.

13. Clement, F.; Suhardiman, D.; Bharati, L. IWRM discourses, institutional Holy Grail and water justice in Nepal. Water Altern. 2017, 10, 870-887.

14. Biswas, A.K.; Varis, O.; Tortajada, C. Integrated Water Resources Management in South and South-East Asia; Oxford University Press: New Deli, India, 2005.

15. Rautanen, S.-L.; van Koppen, B.; Wagle, N. Community-driven multiple use water services: Lessons learned by the rural Village water resources management project in Nepal. Water Altern. 2014, 7, 160-177.

16. Lankford, B.A. From Integrated to Expedient: An Adaptive Framework for River Basin Management in Developing Countries; International Water Management Institute: Colombo, Sri Lanka, 2007.

17. Union of Myanmar. Request for Proposal for the Services for C1.17-Development of the Ayeyarwady Decision Support System and Basin Master Plan; Directorate of Water Resources and Improvement of River Systems, Project Management Unit, Union of Myanmar: Naypyitaw, Myanmar, 2017; (unpublished document).

18. Foran, T. Large hydropower and legitimacy: A policy regime analysis, applied to Myanmar. Energy Policy 2017, 110, 619-630. [CrossRef]

19. Rasul, G. Beyond hydropower: Towards an integrated solution for water, energy and food security in South Asia. Int. J. Water Resour. Dev. 2019, 62, 1-25. [CrossRef]

20. Suhardiman, D. The politics of river basin planning and state transformation processes in Nepal. Geoforum 2018, 96, 70-76. [CrossRef]

21. Molle, F.; Foran, T.; Käkönen, M. Contested Waterscapes in the Mekong Region: Hydropower, Livelihoods, and Governance; Earthscan: London, UK, 2009.

22. Conca, K. Expert Networks: The Elusive Quest for Integrated Water Resources Management, in Governing Water: Contentious Transnational Politics and Global Institution Building; Conca, K., Ed.; MIT Press: Cambridge, MA, USA, 2006; pp. 123-165.

23. Foran, T. Rivers of Contention: Pak Mun Dam, Electricity Planning, and State-Society Relations in Thailand, 1932-2004; University of Sydney: Sydney, Austrilia, 2006.

24. McCaughey, D.; Bruning, N.S. Rationality versus reality: The challenges of evidence-based decision making for health policy makers. Implement. Sci. 2010, 5, 39-59. [CrossRef]

25. Zey, M. Criticisms of Rational Choice Models, in Decision Making: Alternatives to Rational Choice Models; Sage Publications, Inc: Thousand Oaks, CA, USA, 1992; pp. 9-31.

26. Stokey, E.; Zeckhauser, R. A Primer for Policy Analysis; W. W. Norton \& Company: New York, NY, USA, 1978. 
27. Lepenies, R. Discovering the Political Implications of Coproduction in Water Governance. Water 2018, 10, 1475. [CrossRef]

28. Edelenbos, J.; van Buuren, A.; van Schie, N. Co-producing knowledge: Joint knowledge production between experts, bureaucrats and stakeholders in Dutch water management projects. Environ. Sci. Policy 2011, 14, 675-684. [CrossRef]

29. Wyborn, C.A. Connecting knowledge with action through coproductive capacities: Adaptive governance and connectivity conservation. Ecol. Soc. 2015, 20, 11. [CrossRef]

30. Tress, G.; Tress, B.; Fry, G. Clarifying Integrative Research Concepts in Landscape Ecology. Landsc. Ecol. 2005, 20, 479-493. [CrossRef]

31. IFC. Strategic Environmental Assessment of the Hydropower Sector in Myanmar. Final Report; International Finance Corporation (IFC): Washington, DC, USA, 2018.

32. Arcadis. Integrated Ayeyarwady Delta Strategy. Delta Report. Final version (2.2); Arcadis: Yangon, Myanmar, 2018.

33. HIC. Ayeyarwady State of the Basin Assessment (SOBA) 2017: Synthesis Report, Volume 1, Yangon, December 2017; Hydro-Informatics Centre: Yangon, Myanmar, 2017.

34. Transparency International Nepal. A Study of Nepal's Hydro Power Sector; Transparency International Nepal: Kathmandu, Nepal, 2016.

35. Shrestha, R.S. Hydropower Development: Before and After 1992. Hydro Nepal J. Water Energy Environ. 2016, 18, 16-21. [CrossRef]

36. WECS. Section 7. Terms of Reference [Power Sector Reform and Sustainable Hydropower Development Project and Strategic Environmental and Social Assessment]; Water and Energy Commission Secretariat: Kathmandu, Nepal, 2016.

37. OUP. Oxford English Dictionary. In OED Online; Oxford University Press: Oxford, UK, 2000.

38. Fairclough, I.; Fairclough, N. Political Discourse Analysis: A Method for Advanced Students; Routledge: Oxon, UK, 2012.

39. Crawford, S.E.S.; Ostrom, E. A Grammar of Institutions. Am. Political Sci. Rev. 1995, 89, 582-600. [CrossRef]

40. Basurto, X. A Systematic Approach to Institutional Analysis: Applying Crawford and Ostrom's Grammar. Political Res. Q. 2010, 63, 523-537. [CrossRef]

41. Hurlbert, M.A.; Gupta, J. An institutional analysis method for identifying policy instruments facilitating the adaptive governance of drought. Environ. Sci. Policy 2019, 93, 221-231. [CrossRef]

42. Neef, A. Transforming Rural Water Governance: Towards Deliberative and Polycentric Models? Water Altern. 2009, 2, 53-60.

43. Burgess, J. Deliberative mapping: A novel analytic-deliberative methodology to support contested science-policy decisions. Public Underst. Sci. 2007, 16, 299-322. [CrossRef]

44. Gastil, J.; Levine, P. The Deliberative Democracy Handbook: Strategies for Effective Civic Engagement in the Twenty-First Century; Jossey-Bass: San Francisco, CA, USA, 2005.

45. Lane, S.N. Doing flood risk science differently: An experiment in radical scientific method. Trans. Inst. Br. Geogr. 2011, 36, 15-36. [CrossRef]

46. Carr, G. Stakeholder and public participation in river basin management-An introduction. Wiley Interdiscip. Rev. Water 2015, 2, 393-405. [CrossRef]

47. Straton, A.T. Exploring and Evaluating Scenarios for a River Catchment in Northern Australia Using Scenario Development, Multi-criteria Analysis and a Deliberative Process as a Tool for Water Planning. Water Resour. Manag. 2011, 25, 141-164. [CrossRef]

48. Hajkowicz, S.; Collins, K. A Review of Multiple Criteria Analysis for Water Resource Planning and Management. Water Resour. Manag. 2007, 21, 1553-1566. [CrossRef]

49. Emerson, K.; Nabatchi, T.; Balogh, S. An Integrative Framework for Collaborative Governance. J. Public Adm. Res. Theory 2012, 22, 1-29. [CrossRef]

50. Alford, J.; Head, B.W. Wicked and less wicked problems: A typology and a contingency framework. Policy Soc. 2017, 36, 397-413. [CrossRef]

51. Pahl-Wostl, C. Water Governance in the Face of Global Change: From Understanding to Transformation; Springer International Publishing: Cham, Switzerland, 2015. 
52. Pahl-Wostl, C.; Knieper, C. The capacity of water governance to deal with the climate change adaptation challenge: Using fuzzy set Qualitative Comparative Analysis to distinguish between polycentric, fragmented and centralized regimes. Glob. Environ. Chang. 2014, 29, 139-154. [CrossRef]

53. AWP. Activity Plan. Activity 5: Ayeyarwady Exploratory Basin Scoping Exercise; Australian Water Partnership: Canberra, Australia, 2017; (unpublished document).

54. Costanza, R. Planning Approaches for Water Resources Development in the Lower Mekong Basin; Portland State University, Mae Fah Luang University: Portland, OR, USA, 2011.

55. Suhardiman, D.; Clement, F.; Bharati, L. Integrated water resources management in Nepal: Key stakeholders' perceptions and lessons learned. Int. J. Water Resour. Dev. 2015, 31, 284-300. [CrossRef]

56. Jalsrot Vikas Sanstha and Policy Entrepreneurs Inc. Formulation of Basin Development Goals and Pathways: For Delivery of Stakeholder Participation and Strategy Development in the Kamala River Basin, Nepal; Jalsrot Vikas Sanstha, Policy Entrepreneurs Inc.: Kathmandu, Nepal, 2018.

57. JICA. Master Plan Study on the Kosi River Water Resources Development. Final Report. March 1985; Japan International Cooperation Agency: Tokyo, Japan, 1985. Available online: http://open_jicareport.jica.go.jp/ pdf/10313831_01.pdf (accessed on 24 November 2019).

58. JICA. Preparatory survey on JICA's Cooperation Program for Agriculture and Rural Development in Nepal-Food Production and Agriculture in Terai-Final Report; Japan International Cooperation Agency: Tokyo, Japan, 2013. Available online: http://open_jicareport.jica.go.jp/pdf/12127288.pdf (accessed on 24 November 2019).

59. Montibeller, G. Behavioral Challenges in Policy Analysis with Conflicting Objectives. In Recent Advances in Optimization and Modeling of Contemporary Problems; Institute for Operations Research and the Management Sciences (INFORMS): Catonsville, MD, USA, 2018; pp. 85-108.

60. CSIRO; WECS. State of the Water Resources in the Kamala Basin, Nepal; CSIRO Land and Water: Canberra, Australia. (in press)

61. Carson, L.; Hartz-Karp, J. Adapting and Combining Deliberative Designs. Juries, Polls, and Forums. In The Deliberative Democracy Handbook: Strategies for Effective Civic Engagement in the Twenty-First, Century; Gastil, J., Levine, P., Eds.; Jossey-Bass: San Francisco, CA, USA, 2005.

62. Tan, P.-L.; Bowmer, K.H.; Mackenzie, J. Deliberative tools for meeting the challenges of water planning in Australia. J. Hydrol. 2012, 474, 2-10. [CrossRef]

63. Hughey, K.F.D.; Jacobson, C.L.; Smith, E.F. A framework for comparing collaborative management of Australian and New Zealand water resources. Ecol. Soc. 2017, 22, 28. [CrossRef]

64. Benson, D.; Jordan, A.; Smith, L. Is Environmental Management Really More Collaborative? A Comparative Analysis of Putative 'Paradigm Shifts' in Europe, Australia, and the United States. Environ. Plan. A Econ. Space 2013, 45, 1695-1712. [CrossRef]

65. Maclean, K.; Cullen, L. Research methodologies for the co-production of knowledge for environmental management in Australia. J. R. Soc. NZL 2009, 39, 205-208. [CrossRef]

66. Pahl-Wostl, C. The role of governance modes and meta-governance in the transformation towards sustainable water governance. Environ. Sci. Policy 2019, 91, 6-16. [CrossRef]

67. Alston, M. Water policy, trust and governance in the Murray-Darling Basin. Aust. Geogr. 2016, 47, 49-64. [CrossRef]

(C) 2019 by the authors. Licensee MDPI, Basel, Switzerland. This article is an open access article distributed under the terms and conditions of the Creative Commons Attribution (CC BY) license (http://creativecommons.org/licenses/by/4.0/). 